\title{
Endo-pectinase Production by Bacillus pumilus NRRL B-212 and Optimization by RSM using Sugar Beet Pulp
}

\author{
O. Tepe* and A. Y. Dursun \\ Department of Environmental Engineering, \\ Faculty of Engineering, \\ Firat University, 23119, \\ Elazığ, Turkey
}

doi: https://doi.org/10.15255/CABEQ.2021.1978

Original scientific paper

Received: June 7, 2021 Accepted: November 15, 2021

\begin{abstract}
The present study aimed at optimization of culture conditions for endo-pectinase production by Bacillus pumilus NRRL B-212. In the first stage of the study, submerged fermentation experiments were performed to investigate effects of initial $\mathrm{pH}$, carbon and nitrogen sources, salts and phosphate on endo-pectinase activity and maximum enzyme production was at $\mathrm{pH}$ : 8 . The effect of initial pectin concentration on enzyme production was examined, and $1 \%(\mathrm{w} / \mathrm{v})$ pectin concentration was selected as the optimum pectin concentration. Yeast extract, $\left(\mathrm{NH}_{4}\right)_{2} \mathrm{SO}_{4}$, and peptone were used as nitrogen sources, and the medium containing $0.05 \%(\mathrm{w} / \mathrm{v})$ ammonium sulphate was the medium where maximum activity was achieved. In the experiments investigating the effect of salts, the maximum activity value was determined in the medium containing $0.02 \% \mathrm{NaCl}$. In addition, the effect of phosphate concentration on enzyme production was investigated, and the highest endo-pectinase activity was determined in medium containing $0.3 \% \mathrm{~K}_{2} \mathrm{HPO}_{4}+$ $0.15 \% \mathrm{KH}_{2} \mathrm{PO}_{4}$. In the second stage of the study, solid-state fermentation studies were performed, and sugar beet pulp was used as agricultural waste. In order to obtain maximum endo-pectinase production and reveal the parameters influencing enzyme activity using sugar beet pulp, a Central Composite Design (CCD) was applied. The highest endo-pectinase activity was obtained as $147.75 \mathrm{U} \mathrm{mL}^{-1}$ in medium containing $6.78 \%$ sugar beet pulp, $0.48 \%\left(\mathrm{NH}_{4}\right)_{2} \mathrm{SO}_{4}$ and $0.12 \%$ yeast extract.
\end{abstract}

Keywords:

Bacillus pumilus NRRL B-212, endo-pectinase, enzyme production, response surface methodology, submerged fermentation, sugar beet pulp

\section{Introduction}

Pectins are persistent and high molecular weight compounds with heteropolysaccharide structure found colloidally between cells, in cell membranes, and middle lamellar regions in almost all plants. ${ }^{1,2}$ Pectinases break down pectic substances through de-esterification and depolymerization reactions. ${ }^{1}$ Pectinases can generally be classified under three headings as pectin hydrolase, pectin lyase, and pectin esterase. ${ }^{2}$ When pectinases are classified depending on the source of the microorganisms used for production, those obtained from the fungal source can be called acidic pectinases, and those obtained from the bacterial source can be called basic pectinases.

They are used in many industries such as paper bleaching, beverage industry, oil extraction from seeds, coffee and tea fermentation, fruit and vegetable processing, bio-cleaning of cotton fibers, degumming of plant fibers, and wastewater treatment. Recently, they are the enzymes with the highest

${ }^{*}$ Corresponding author: e-mail: otepe $@$ firat.edu.tr market value among the enzymes used in industries. $^{3}$ The market size of the pectinase enzyme is estimated at approximately $\$ 35.5$ million by 2021 . Due to the excessive use of these enzymes in various industries, it is imperative to develop a new strategy that can provide maximum enzyme yield in a short time with minimum production cost by using cheap substrates. For this reason, the use of agricultural wastes in enzyme production has been taken into account, as agricultural wastes are rich in hemicellulose, cellulose, and pectin, and can also be obtained easily, their use is economical and minimizes pollution. ${ }^{4}$

Sugar beet is an important crop for sugar production. As by-products in sugar industry, sugar beet pulp is produced in large amounts annually, which causes disposal problems. ${ }^{5-7}$ In 2019,14 million metric tons of sugar beet pulp were produced globally as dry matter. ${ }^{8}$ Sugar beet pulp, which is mostly used as animal feed, contains approximately $30 \%$ hemicellulose, $15-25 \%$ pectin, and $22-24 \%$ cellulose, and can be used as a raw material for the production of various enzymes. ${ }^{5}$ 
Many studies have been performed on the use of sugar beet pulp for the production of various enzymes. For example, Mihajlovski et al. ${ }^{5}$ examined $\beta$-amylase production using sugar beet pulp and molasses, and a maximum enzyme production 2.237 $\mathrm{U} \mathrm{mL} \mathrm{m}^{-1}$ was obtained at $3 \%$ sugar beet pulp concentration. Li et al. ${ }^{9}$ obtained $3600 \mathrm{U} \mathrm{g}^{-1}$ polygalacturonase activity at $35{ }^{\circ} \mathrm{C}$ in 48 hours using sugar beet pulp. Taşkın and Eltem ${ }^{10}$ used different mixtures of agricultural wastes, including sugar beet pulp, to enhance the enzyme yield. Polygalacturonase and polymethylgalacturonase activities were $385 \pm 12.3 \mathrm{U} \mathrm{g}^{-1}$ on day 3 and $18.3 \pm 3.2 \mathrm{U} \mathrm{g}^{-1}$ on the day 2 , respectively. Tepe and Dursun ${ }^{11}$ used sugar beet pulp, yeast extract, and $\left(\mathrm{NH}_{4}\right)_{2} \mathrm{SO}_{4}$ to produce exo-pectinase. The highest enzyme production of $33.43 \mathrm{U} \mathrm{mL}^{-1}$ was obtained at sugar beet pulp amount of $6.78 \%(\mathrm{w} / \mathrm{v})$, ammonium sulphate concentration of $0.48 \%(\mathrm{w} / \mathrm{v})$, and yeast extract concentration of $0.48 \%(\mathrm{w} / \mathrm{v})$. Cheilas et al. ${ }^{12}$ obtained $0.25 \mathrm{U} \mathrm{mL}^{-1}$ arabinanase activity in medium using sugar beet pulp $(4 \%, \mathrm{w} / \mathrm{v})$.

In classical optimization methods, the effect of each parameter on fermentation processes is examined one by one. However, optimization of media components using such methods has several disadvantages. For example, these methods require a great deal of trials and time. In addition, in multivariate systems, these methods are sometimes not sufficient to explain interactions between variables. Therefore, in recent years, statistical methods have replaced classical methods. Response Surface Methodology (RSM) is one of the most used statistical methods. ${ }^{13}$

The main purpose of this study was to test the ability of Bacillus pumilus NRRL B-212 on endopectinase production. Endo-pectinase production was carried out by submerged fermentation in a batch system, and the effects of initial $\mathrm{pH}$, carbon and nitrogen sources, salts and phosphate on endo-pectinase activity were investigated. Further, in solid-state fermentation experiments, sugar beet pulp was selected as the carbon source for endo-pectinase production and supplemented with yeast extract and $\left(\mathrm{NH}_{4}\right)_{2} \mathrm{SO}_{4}$. $\mathrm{RSM}$ was used to study the effects of sugar beet pulp, $\left(\mathrm{NH}_{4}\right)_{2} \mathrm{SO}_{4}$, and yeast extract concentrations on endo-pectinase production, and their dosages were optimized. In the literature, most studies on pectinases highlight the production and applications of acidic pectinases, and there are only a few reports on the fermentation and applications of alkaline pectinases. Similarly, pectinase is mainly produced by filamentous fungi, but studies focusing on the use of bacteria in endo-pectinase production are still lacking. The results of this study will complement the deficiencies in the literature regarding the use of bacteria in al- kaline pectinase production, and will reveal that sugar beet pulp has a high potential in the production of endo-pectinase. In addition, these results will be a guide for the industries where this enzyme is used.

\section{Materials and methods}

\section{Chemicals}

Pectin from apple was purchased from Sigma (USA). Glucose, yeast extract, peptone, $\left(\mathrm{NH}_{4}\right)_{2} \mathrm{SO}_{4}$, $\mathrm{MgSO}_{4} \cdot 7 \mathrm{H}_{2} \mathrm{O}$ were purchased from Merck (Germany). $\mathrm{KH}_{2} \mathrm{PO}_{4}, \mathrm{~K}_{2} \mathrm{HPO}_{4}$ were purchased from Sigma-Aldrich (USA). All chemicals were of analytical purity.

\section{Culture conditions}

The Bacillus pumilus NRRL B-212 was grown at $30{ }^{\circ} \mathrm{C}$ and $\mathrm{pH} 7$ in nutrient solution. Nutrient solution was sterilized at $1.1 \mathrm{~atm}, 121{ }^{\circ} \mathrm{C}$ for $20 \mathrm{~min}$. Bacteria production was performed in an agitated shaker (100 rpm) (Gallenkamp) for 24 h. ${ }^{14}$ The nutrient solution contained amounts given per L; glucose, $3 \mathrm{~g}$; yeast extract, $2 \mathrm{~g}$; peptone, $2 \mathrm{~g}$; $\mathrm{KH}_{2} \mathrm{PO}_{4}$, $1 \mathrm{~g} ; \mathrm{K}_{2} \mathrm{HPO}_{4}, 1 \mathrm{~g} ;\left(\mathrm{NH}_{4}\right)_{2} \mathrm{SO}_{4}, 1 \mathrm{~g} ; \mathrm{MgSO}_{4} \cdot 7 \mathrm{H}_{2} \mathrm{O}$, $0.05 \mathrm{~g}$. The flasks containing active bacteria were stored at $4{ }^{\circ} \mathrm{C}$ in the refrigerator. Microorganism stored in the refrigerator was transferred to a new nutrient medium every 15 days to keep the microorganism active. After incubation, the microorganisms were transferred into the pectinase fermentation medium (in a 1:10 ratio).

\section{Endo-pectinase production by submerged fermentation}

Endo-pectinase was produced under submerged fermentation in 500-mL Erlenmeyer flasks containing $150 \mathrm{~mL}$ of enzyme production medium $(\% \mathrm{w} / \mathrm{v}$ : apple pectin, 1; $\left(\mathrm{NH}_{4}\right)_{2} \mathrm{SO}_{4}, 0.14 ; \mathrm{KH}_{2} \mathrm{PO}_{4}, 0.2$; $\left.\mathrm{K}_{2} \mathrm{HPO}_{4}, 0.6 ; \mathrm{MgSO}_{4} \cdot 7 \mathrm{H}_{2} \mathrm{O}, 0.01\right)$ at 150 rpm shaking conditions. ${ }^{6}$ After sterilization by autoclaving (pectin solution was autoclaved separately), the $\mathrm{pH}$ of the solution was adjusted with diluted $\mathrm{H}_{2} \mathrm{SO}_{4}$ or $\mathrm{NaOH}$ solutions using a $\mathrm{pH}$ meter (Orion 3 STAR). In submerged experiments, samples were taken at intervals of $12 \mathrm{~h}$ for $108 \mathrm{~h}$ to determine the effect of initial $\mathrm{pH}$ on endo-pectinase production. Samples were taken at intervals of $4 \mathrm{~h}$ during the first $24 \mathrm{~h}$ in other experiments. Four samples per day between $24 \mathrm{~h}$ and $108 \mathrm{~h}$ and 1 sample per day between 108 $\mathrm{h}$ and $180 \mathrm{~h}$ were taken. The enzyme was not extracted. The enzyme activity measurements were performed in the clear supernatant obtained from the samples of $5 \mathrm{~mL}$ centrifuged at $5000 \mathrm{rpm}$ for 5 minutes (Nüve NF 800R). 
Production of endo-pectinase with sugar beet pulp by solid-state fermentation

Sugar beet pulp $(5 \% \mathrm{w} / \mathrm{v})$ was obtained from a local sugar factory in Elazığ, Turkey. Firstly, it was washed and then oven-dried at $60{ }^{\circ} \mathrm{C}$ for $24 \mathrm{~h}$. The dried material was milled using ball mill (CENMKII-Solids Handling Studies, Armfield Ltd. Ringwood Hampshire England), and sieved (20100 mesh). The solid material was placed in Erlenmeyer flasks $(250 \mathrm{~mL})$ for enzyme production. The flasks were sterilized for 15 minutes at a temperature of $121{ }^{\circ} \mathrm{C}$ and cooled to room temperature. Tap water was used for hydrating the dried materials. After inoculation with liquid culture $(10 \%, \mathrm{v} / \mathrm{v})$, enzyme production experiments were conducted at $30{ }^{\circ} \mathrm{C}, \mathrm{pH} 8$, and $150 \mathrm{rpm}$. In solid-state fermentation experiments, samples were taken every $24 \mathrm{~h}$. The enzyme activity measurements were performed on samples of $10 \mathrm{~mL}$ centrifuged at $5000 \mathrm{rpm}$ for 5 minutes.

\section{Determination of endo-pectinase activity}

Endo-pectinase activity was measured viscosimetrically using a Vibroviscometer (SV10, Sine Wave Vibro Viscometer, A\&D Engineering). ${ }^{15,16}$ The reaction mixtures consisted of $1 \mathrm{~mL}$ of enzyme solution and $19 \mathrm{~mL}$ of $0.5 \%(\mathrm{w} / \mathrm{v})$ apple pectin in a $0.05 \mathrm{M}$ glycine- $\mathrm{NaOH}$ buffer $(\mathrm{pH} 10.5$ on submerged fermentation and $\mathrm{pH} 10$ on medium with sugar beet pulp). This solution was heated at $60{ }^{\circ} \mathrm{C}$ $\left(30^{\circ} \mathrm{C}\right.$ on medium with sugar beet pulp) for $15 \mathrm{~min}$. After incubation, the reduction in viscosity was monitored by a Vibroviscometer. Under these conditions, the enzyme quantity reduced the initial solution viscosity by $50 \%$ per minute, and this was determined as one unit of endo-pectinase activity.

\section{Statistical analysis}

RSM comprises a set of experimental techniques concerned with evaluating the relationship between a set of independent variables and responses in the experiment, in accordance with predetermined criteria. To obtain a more realistic model, preliminary information of the process and process factors are required. In the development of the regression equation, the test factors are coded in accordance with the following equation.

$$
X_{i}=\frac{U_{i}-U_{i}^{0}}{\Delta U_{i}}
$$

where $X_{i}, U_{i}, U_{i}^{0}$ and $\Delta U_{i}$ are the coded value of an independent variable, real value of an independent variable, real value of an independent variable at centre point, and the step change, respectively. To correlate the response variable to the independent variables, it was fitted with a quadratic model. The quadratic polynomial equation is:

$$
Y=b_{0}+\sum_{i=1}^{n} b_{i} X_{i}+\sum_{i=1}^{n} b_{i i} X_{i}^{2}+\sum_{i=1}^{n} \sum_{j=i+1}^{n} b_{i j} X_{i} X_{j}
$$

where $n, Y, X, X_{i}$ and $b_{0}$ are the number of independent variables, the predicted response, independent variables, and the intercept term, respectively. $b_{i}, b_{i i}$ and $b_{i j}$ are the coefficients for the linear, quadratic, and interaction effects, respectively.

A $2^{3}$ full factorial central composite design (CCD) for three independent variables consists of six axial points and eight factorial points, and six replicates around a center point. It was applied to fit a quadratic polynomial model. Design-Expert software (Ver. 7.0 Stat Ease Inc.) was used to calculate and analyze of the quadratic polynomial coefficients. The fit of the model was performed by analysis of variance (ANOVA). It included probability value $(P)$, Fisher's F-test, and determination coefficient $R$. The model is represented as three-dimensional and contour plots. ${ }^{17}$

\section{Optimization of endo-pectinase production by RSM}

On endo-pectinase production with sugar beet pulp, the relationship between the substrates and enzyme production was investigated using RSM. A Central Composite Design (CCD) was applied to reveal the parameters influencing enzyme activity. The values of $k$ and $\alpha$ were equal to 3 and 1.68, respectively. Sugar beet pulp (A), $\left(\mathrm{NH}_{4}\right)_{2} \mathrm{SO}_{4}(\mathrm{~B})$, and yeast extract $(\mathrm{C})$ concentrations were used as numeric factors. To obtain a second order response surface, their quantities were changed at five levels $(-\alpha,-1,0,+1,+\alpha)($ Table 1$)$. Twenty experiments were planned. These experiments contained six axial points and eight factorial points with six replicates around center point (Table 2). Samples were taken every $24 \mathrm{~h}$. The maximum endo-pectinase ac-

Table 1 -Codified levels for the factors in CCD

\begin{tabular}{c|c|c|c|c|c|c}
\hline \multirow{2}{*}{$\begin{array}{c}\text { Independent variables } \\
\text { (concentration, w/v \%) }\end{array}$} & \multirow{2}{*}{ Symbol code } & \multicolumn{5}{|c}{ Range and levels } \\
\cline { 3 - 7 } & & $-1.68(-\alpha)$ & -1 & 0 & +1 & $+1.68(+\alpha)$ \\
\hline Sugar beet pulp & $\mathrm{A}$ & 2.0 & 3.22 & 5.0 & 6.78 & 8.0 \\
Ammonium sulphate & $\mathrm{B}$ & 0.0 & 0.12 & 0.3 & 0.48 & 0.6 \\
Yeast extract & $\mathrm{C}$ & 0.0 & 0.12 & 0.3 & 0.48 & 0.6 \\
\hline
\end{tabular}


tivity values obtained on day 7 were used as the response of the design experiments. Design-Expert software Ver 7.0 (Stat Ease Inc.) statistical package was used to calculate and analyze the second-order polynomial coefficients. Interaction factors were included. The fit of the model was performed by analysis of variance (ANOVA).

\section{Results and discussion}

\section{Endo-pectinase production by submerged fermentation}

\section{Effect of initial pH}

One of the most important factors affecting the growth of microorganism, cell membrane permeability, enzyme biosynthesis, and preservation of stability is the initial $\mathrm{pH}$ of the medium. The optimum $\mathrm{pH}$ for the production of pectic enzymes in many fungal species is in the acidic range, and the basic range for bacteria. ${ }^{18}$ In submerged culture fermentation, the initial $\mathrm{pH}$ of the medium was changed
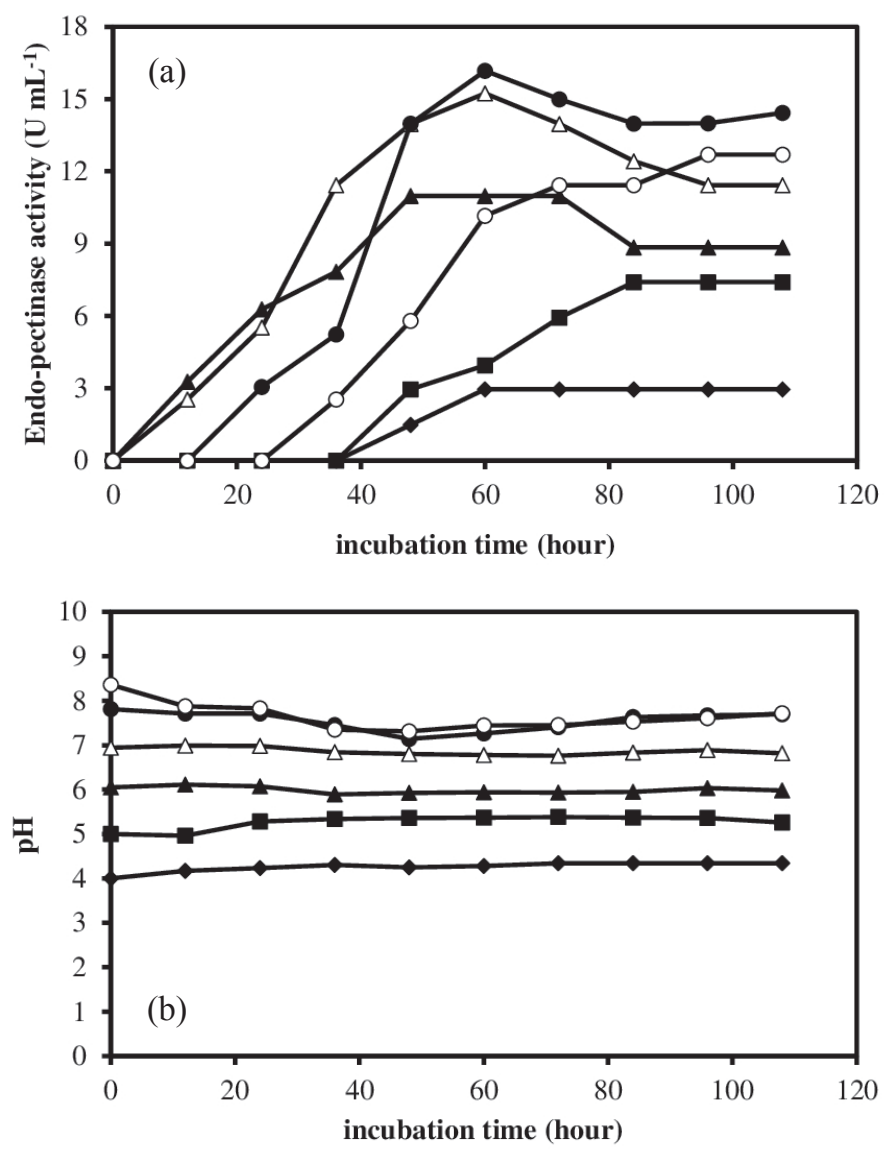

Fig. $1-a)$ Effect of initial $\mathrm{pH}$ on endo-pectinase production by Bacillus pumilus NRRL B-212 b) change in medium $\mathrm{pH}$ over time at different $\mathrm{pH}$ values $\left(T: 30{ }^{\circ} \mathrm{C}\right.$, agitation rate: $150 \mathrm{rpm}$, Cpectin: $1 \%(w / v),: p H 4, \mathbf{a}: p H 5, \boldsymbol{\Delta}: p H 6, \Delta: p H 7, \bullet: p H$ 8, o: $p H$ 9) between 4-9 in order to determine the effect of medium $\mathrm{pH}$ on the production of endo-pectinase. Endo-pectinase activity values obtained at different $\mathrm{pH}$ values are given in Fig. 1(a). Maximum endopectinase activity was obtained as $16.17 \mathrm{U} \mathrm{mL}^{-1}$ at $60 \mathrm{~h}$ at $\mathrm{pH} 8$. There was less enzyme production at lower and higher $\mathrm{pH}$ values, and $\mathrm{pH} 8$ was used as the $\mathrm{pH}$ value of the culture medium in the future studies. In the literature, it is stated that the optimum $\mathrm{pH}$ for the growth of most bacteria and the production of pectinase group enzymes varies between 7.0-10.0. ${ }^{19}$ Fig. 1(b) shows the change in $\mathrm{pH}$ of the fermentation medium over time at various initial $\mathrm{pH}$ values. The $\mathrm{pH}$ of the mediums at $\mathrm{pH} 4$, 5,6 , and 7 remained at the same level without much change over time. Assumed was that the $\mathrm{pH}$ of the medium kept constant due to the presence of $\mathrm{KH}_{2} \mathrm{PO}_{4}$ and $\mathrm{K}_{2} \mathrm{HPO}_{4}$, which acted as buffers. The $\mathrm{pH}$ values of 8 and 9 decreased to a certain value over time, and then started to increase slightly. This similar change in the $\mathrm{pH}$ of the environment during pectinase production has also been observed by various researchers. ${ }^{20}$

\section{Effect of initial pectin concentration}

In fermentation experiments, one of the most important parameters affecting enzyme production is the initial substrate concentration. Pectin functions as an inducer in pectinase production in microbial systems. ${ }^{21}$ The initial pectin concentration was varied between $0.5-2.0 \%(\mathrm{w} / \mathrm{v})$, and its effect on endo-pectinase activity was investigated. As seen in Fig. 2(a), endo-pectinase activity increased with increasing pectin concentration, and maximum activity was achieved at $2.0 \%$ pectin concentration. The pectin concentration in the fermentation medium changed the enzyme production. Maximum endopectinase activity was determined as $24.73 \mathrm{U} \mathrm{mL}^{-1}$ at $64 \mathrm{~h}$. The change in $\mathrm{pH}$ over time is shown in Fig. 2(b). The $\mathrm{pH}$ of the fermentation medium first decreased and then started to increase over time. The decrease in the $\mathrm{pH}$ of the culture liquid during fermentation may be caused by the accumulation of pectic acids because of the de-esterfication of the pectin. This decrease in $\mathrm{pH}$ may encourage enzyme secretion. ${ }^{22}$ The $\mathrm{pH}$ increase in fermentation processes is related to the release of ammonia as a result of protein metabolism and the use of amino acids as an energy source. Another possible alkali-forming metabolic reaction is the oxidation of organic acid anions. Considering that protein and amino acids are not the main sources of carbon and energy in fermentation, it is clear that this increase in $\mathrm{pH}$ was due to the use of acid. ${ }^{23}$ The results also showed that pectin caused no inhibition of endo-pectinase activity in the concentration range $0.5-2.0 \%(\mathrm{w} / \mathrm{v})$. In the literature, Abbasi and Fa- 

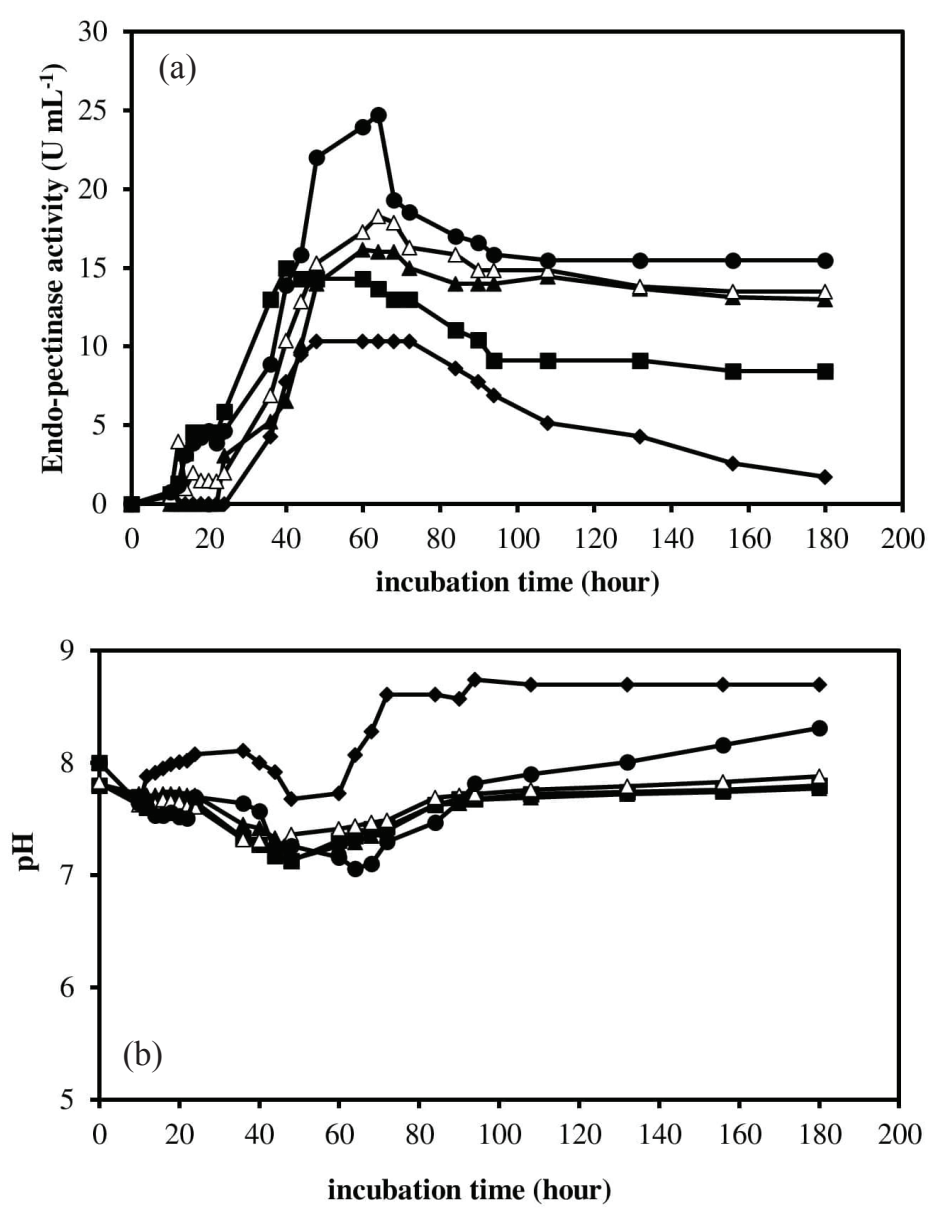

Fig. 2 - a) Effect of different pectin concentrations on endo-pectinase production by Bacillus pumilus NRRL B-212 b) change in medium $\mathrm{pH}$ over time at different pectin concentrations $\left(\mathrm{pH}=8, \mathrm{~T}: 30^{\circ} \mathrm{C}\right.$, agitation rate: $150 \mathrm{rpm}, \uparrow: 0.50 \%$, $\mathbf{\square}$ : $0.75 \%, \boldsymbol{\Delta}: 1 \%, \Delta: 1.50 \%, \bullet: 2 \%(w / v))$

zaelipoor $^{24}$ found that $50 \mathrm{~g} \mathrm{~L}^{-1}$ pectin concentration caused no inhibition of polygalacturonase activity. In the study conducted by Özeş, ${ }^{25}$ it was determined that when pectin and polygalacturonic acid were used as carbon sources, the maximum enzyme synthesis was in samples with a concentration of $2 \%$. It was determined that the enzyme production decreased above $2 \%$ concentration. In our study, pectin concentration of more than $2 \%$ was not used because fermentation medium at $2 \%$ pectin concentration was more viscous, and $1 \%$ pectin concentration was used in subsequent experiments.

\section{Effect of different carbon sources}

It is acknowledged that extracellular pectinase production by microorganisms is promoted by the presence of pectic substances in the culture medium. ${ }^{26}$ However, monosaccharides, disaccharides, and sugar alcohols reduce product yield in pectinase production. Polygalacturonic acid and glucose were used instead of pectin in the fermentation medium in the experiments conducted to determine the effect of different carbon sources on endo-pectinase enzyme production. Endo-pectinase activities obtained at concentrations of $1 \%$ glucose, $1 \%$ and $2 \%$ polygalacturonic acid, and $1 \%$ pectin are given in Fig. 3(a). Maximum endo-pectinase activities obtained in $1 \%$ glucose, $1 \%$ polygalacturonic acid, and $2 \%$ polygalacturonic acid concentrations were $15.24 \mathrm{U} \mathrm{mL}^{-1}$ (at $93 \mathrm{~h}$ ), $14.19 \mathrm{U} \mathrm{mL}^{-1}$ (at $89 \mathrm{~h}$ ), and $4.90 \mathrm{U} \mathrm{mL}^{-1}$ (at $48 \mathrm{~h}$ ), respectively. However, these were lower than endo-pectinase activity value (16.17 $\mathrm{U} \mathrm{mL}^{-1}$ at $64 \mathrm{~h}$ ) obtained in the medium containing $1 \%$ pectin. Polygalacturonic acid is a pectic substance of different molecular weight. The microorganism degraded polygalacturonic acid by secreting different types of pectinolytic enzymes. Ouattara et al., ${ }^{27}$ in their studies with different Bacillus species, found that pectic compounds affect pectinase synthesis, and that Bacillus species can synthesize pectinase in a medium containing little glucose with no pectic substance. The change in $\mathrm{pH}$ value
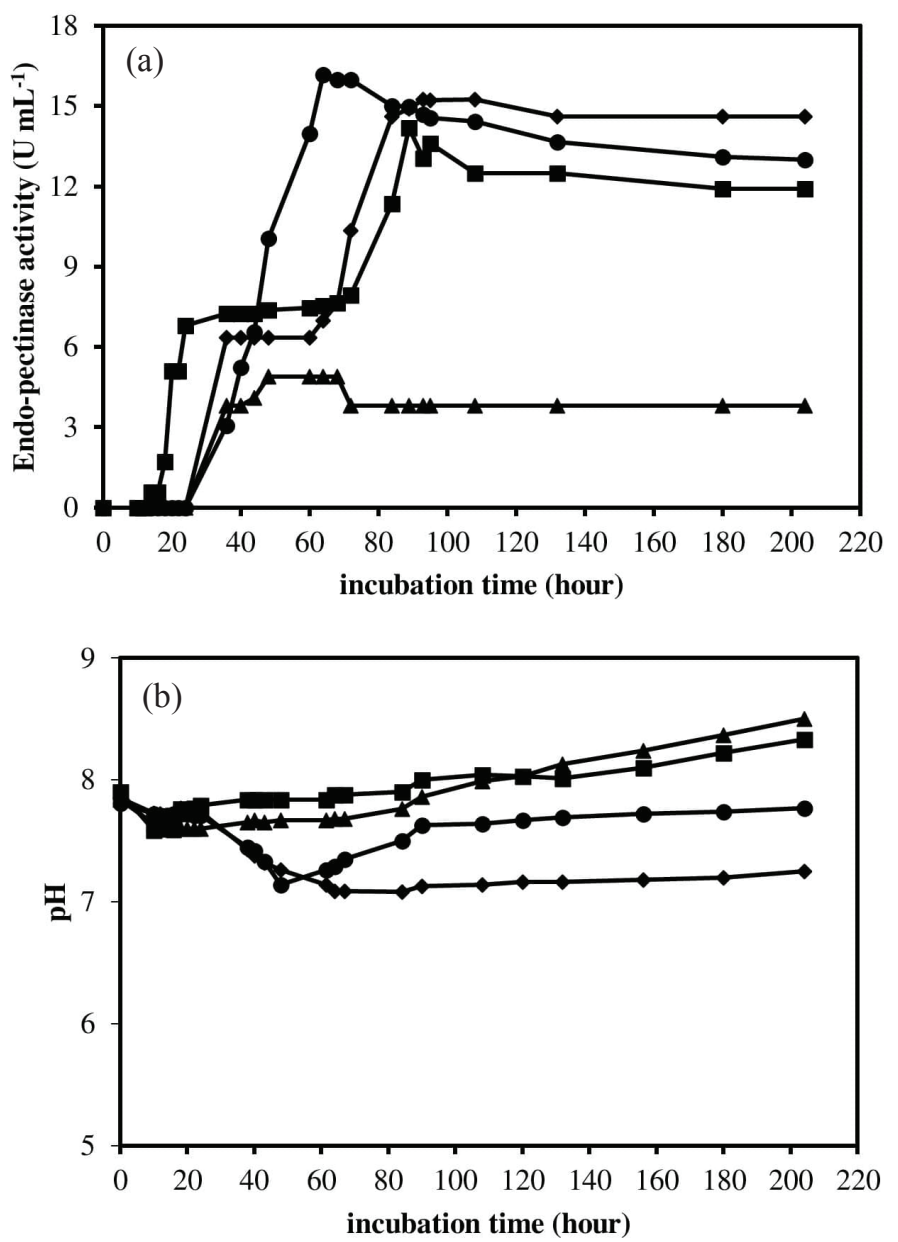

Fig. 3 - a) Effect of different carbon sources on endo-pectinase production by Bacillus pumilus NRRL B-212, b) change in medium $\mathrm{pH}$ over time at different carbon sources $(\mathrm{pH}=8, \mathrm{~T}: 30$ ${ }^{\circ} \mathrm{C}$, agitation rate: $150 \mathrm{rpm},: 1 \%(\mathrm{w} / \mathrm{v})$ glucose, $\mathbf{\square}: 1 \%(\mathrm{w} / \mathrm{v})$ polygalacturonic acid, $\boldsymbol{\Delta}: 2 \%(w / v)$ polygalacturonic acid, $\bullet$ : $1 \%(w / v)$ pectin $)$ 
over time in fermentation media containing different carbon sources is shown in Fig. 3(b). As in other environmental conditions, the $\mathrm{pH}$ decreased to a certain value over time and then increased slightly. There was a greater decrease in $\mathrm{pH}$ in the medium containing $1 \%$ glucose.

\section{Effect of nitrogen sources}

Nitrogen sources and concentrations in the fermentation medium have an important role in enzyme production and microbial growth. ${ }^{28}$ In the experiments conducted to examine the effect of different nitrogen sources on the production of endo-pectinase, other medium components were kept constant, and the nitrogen source was changed. Yeast extract, $\left(\mathrm{NH}_{4}\right)_{2} \mathrm{SO}_{4}$ and peptone were used at the rates of $0.05,0.14$, and $0.3 \%$ as nitrogen sources.

The endo-pectinase activities obtained at different yeast extract concentrations are given in Fig. 4(a). The highest endo-pectinase activity value was obtained in medium containing $0.14 \%$ yeast extract. In the literature, it is stated that if there is not enough nitrogen source in the fermentation medium, the enzyme production will be low but it may cause inhibition of enzyme production at high concentrations. $^{29}$ Maximum endo-pectinase activity was $9.32 \mathrm{U} \mathrm{mL}^{-1}$ at $64 \mathrm{~h}$.

In order to determine the most suitable nitrogen source and increase the endo-pectinase production, ammonium sulphate, an inorganic nitrogen source, was used at the rates of $0.05 \%, 0.14 \%$, and $0.3 \%$ The enzyme activities obtained are given in Fig. 4(b). The highest endo-pectinase activities observed at $0.05 \%, 0.14 \%$, and $0.30 \%$ ammonium sulphate concentrations were $16.73 \mathrm{U} \mathrm{mL}^{-1}$ at $64 \mathrm{~h}$, $16.17 \mathrm{U} \mathrm{mL}^{-1}$ at $68 \mathrm{~h}$, and $7.93 \mathrm{U} \mathrm{mL}^{-1}$ at $132 \mathrm{~h}$, respectively. As seen from the figure, high ammonium sulphate concentrations had an inhibitory effect on endo-pectinase activity. The maximum endopectinase activity was achieved in the medium with $0.05 \%$ ammonium sulphate, and enzyme activity decreased as the concentration of ammonium sulphate increased.

Endo-pectinase activities obtained in fermentation media using peptone as organic nitrogen source are given in Fig. 4(c). Endo-pectinase activity increased with increasing peptone concentration up to $0.14 \%$ peptone concentration, but a decrease in endo-pectinase activity was observed at higher peptone concentration. Maximum endo-pectinase activity was obtained at $0.14 \%$ peptone concentration. The highest endo-pectinase activities at $0.05 \%$, $0.14 \%$, and $0.30 \%$ peptone concentrations were determined as $5.63 \mathrm{U} \mathrm{mL}^{-1}$ at $44 \mathrm{~h}, 14.69 \mathrm{U} \mathrm{mL}^{-1}$ at $120 \mathrm{~h}$, and $5.48 \mathrm{U} \mathrm{mL}^{-1}$ at $96 \mathrm{~h}$, respectively.
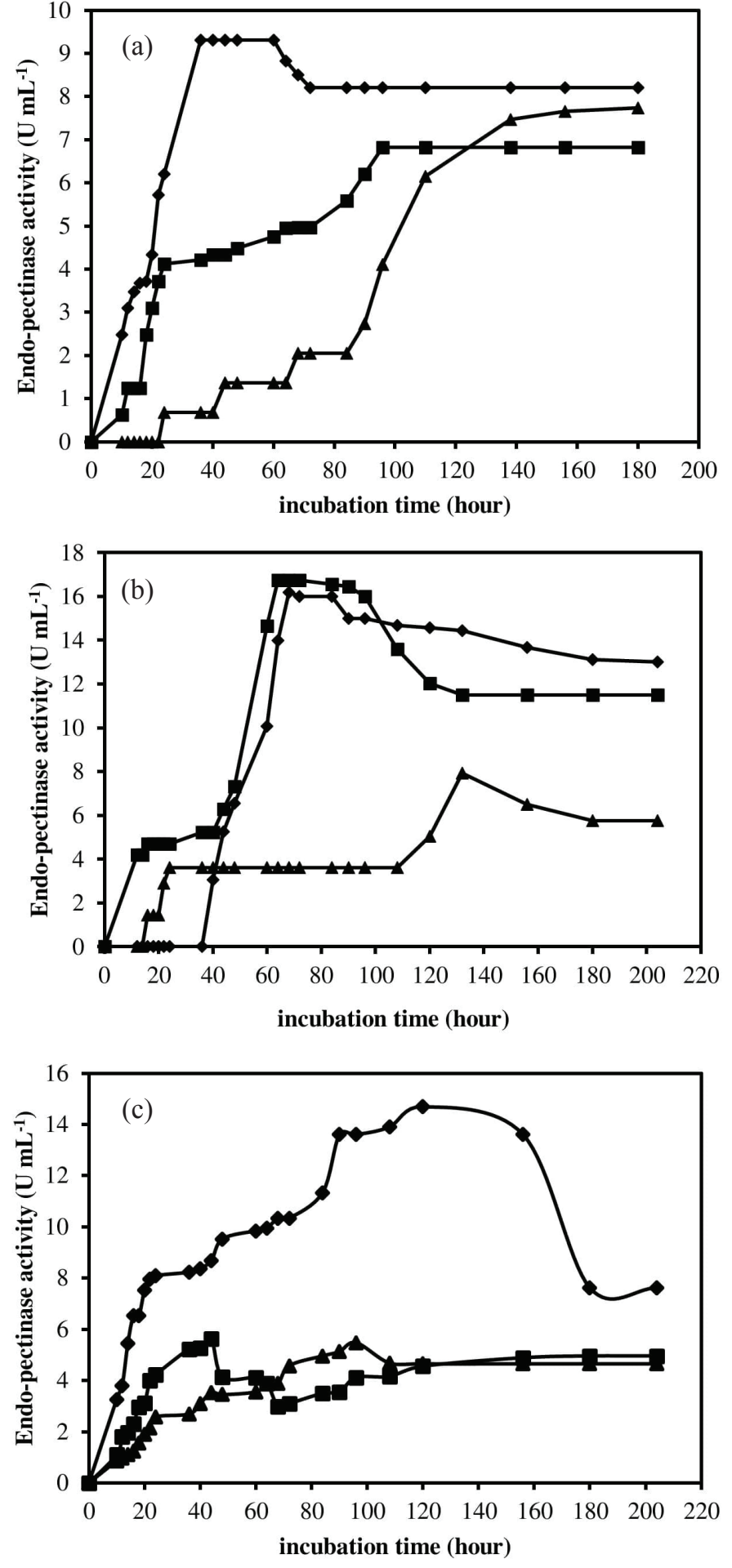

Fig. $4-a)$ Effect of different yeast extracts concentrations b) effect of different ammonium sulphate concentrations c) effect of different peptone concentrations on endo-pectinase production by Bacillus pumilus NKKL B-212 ( $\mathrm{pH}=8, \mathrm{~T}: 30^{\circ} \mathrm{C}$, agitation rate: $150 \mathrm{rpm}$, Cpectin: $1 \%(w / v)$, nitrogen concentrations; $\mathbf{\square}: 0.05 \%,: 0.14 \%, \mathbf{\Delta}: 0.3 \%(w / v))$

When the effects of nitrogen sources were evaluated collectively, it was observed that ammonium sulphate was more useful in the production of endo-pectinase, and it was decided to use ammonium sulphate $(0.05 \%)$ as nitrogen source in further ex- 


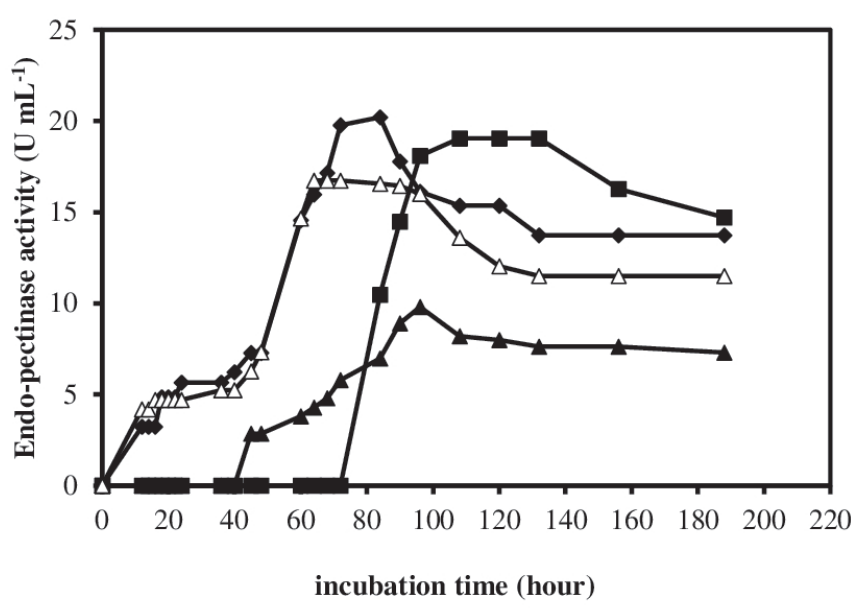

Fig. 5 - Effect of different $\mathrm{CaCl}_{2} \cdot 2 \mathrm{H}_{2} \mathrm{O}$ concentrations on endo-pectinase production by Bacillus pumilus NRRL B-212 $\left(\mathrm{pH}=8, \mathrm{~T}: 30^{\circ} \mathrm{C}\right.$, agitation rate: $150 \mathrm{rpm}$, Cpectin: $1 \%(\mathrm{w} / \mathrm{v})$, calcium chloride concentrations; $\mathbf{\square}: 0.01 \%, \bullet: 0.02 \%, \mathbf{\Delta}$ : $0.04 \%, \Delta: 0.00 \%(w / v))$

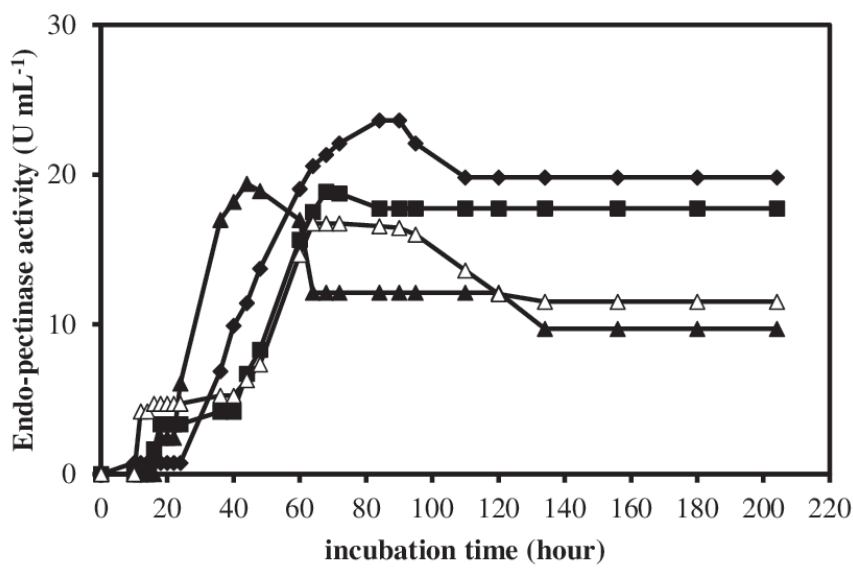

Fig. 6-Effect of different $\mathrm{NaCl}$ concentrations on endo-pectinase production by Bacillus pumilus NRRL B-212 $\left(\mathrm{pH}=8, \mathrm{~T}: 30{ }^{\circ} \mathrm{C}\right.$, agitation rate: $150 \mathrm{rpm}$, Cpecin: $1 \%(\mathrm{w} / \mathrm{v})$, $\mathrm{NaCl}$ concentrations; $\mathbf{\square} 0.01 \%, \quad 0.02 \%, \mathbf{\Delta}: 0.04 \%, \Delta$ : $0.00 \%(w / v))$

periments. The increase in enzyme production caused by ammonium sulphate, which is an inorganic nitrogen source, can be explained by the easier use of $\mathrm{NH}_{4}^{+}$ion in the synthesis of nitrogenous compounds. ${ }^{24}$

\section{Effects of salts and phosphate}

Metal ions are necessary for the growth of microorganisms and may affect enzyme synthesis positively or negatively. In addition, effective metal ions must be present in the environment in order to protect the enzyme stability against proteolytic effects. ${ }^{29}$ Pectinase enzyme production and extracellular performance are directly linked to ions present in solution. The effect of calcium ions on pectinase production with bacteria has been investigated by various researchers. Enzyme production occurs at a low rate because protein secretion is prevented in high metal ion concentrations. ${ }^{19}$ In addition, calcium ions can increase the resistance of the enzyme to high temperatures..$^{30,31}$

To investigate the effect of $\mathrm{CaCl}_{2} \cdot 2 \mathrm{H}_{2} \mathrm{O}$ concentration on endo-pectinase production, experiments were carried out in fermentation mediums containing different concentrations of $\mathrm{CaCl}_{2} \cdot 2 \mathrm{H}_{2} \mathrm{O}$ $\left(0.01,0.02\right.$ and $\left.0.04 \%(\mathrm{w} / \mathrm{v}) \mathrm{CaCl}_{2} \cdot 2 \mathrm{H}_{2} \mathrm{O}\right)$. The findings obtained are given in Fig. 5. With the addition of $\mathrm{CaCl}_{2} \cdot 2 \mathrm{H}_{2} \mathrm{O}$ to the fermentation medium, a certain increase in endo-pectinase activity was observed, the maximum endo-pectinase activity was obtained as $20.20 \mathrm{U} \mathrm{mL}^{-1}$ at $84 \mathrm{~h}$ at $0.02 \%(\mathrm{w} / \mathrm{v})$ $\mathrm{CaCl}_{2} \cdot 2 \mathrm{H}_{2} \mathrm{O}$ concentration.

At the stage where the effect of $\mathrm{NaCl}$ on endo-pectinase activity was investigated, activity values in mediums containing three different concentrations of $\mathrm{NaCl}$ were determined. The findings obtained are given in Fig. 6. As seen in Fig. 6, with the addition of $\mathrm{NaCl}$, the endo-pectinase activity value increased up to $0.02 \%(\mathrm{w} / \mathrm{v}) \mathrm{NaCl}$ concentration, and then decreased. Maximum endo-pectinase activity was measured as $23.62 \mathrm{U} \mathrm{mL}^{-1}$ at $84 \mathrm{~h}$ at $0.02 \%(\mathrm{w} / \mathrm{v}) \mathrm{NaCl}$ concentration. Gummadi et al., ${ }^{32}$ in their study investigating the effect of salts on pectinase production, stated that the specific growth rate of Debaryomyces nepalensis was not affected up to $1 \mathrm{M} \mathrm{KCl}$ concentration, but it was affected by the addition of $\mathrm{NaCl}$ and $\mathrm{LiCl}$. They stated that this low tolerance of Debaryomyces nepalensis against $\mathrm{Na}^{+}$is due to the toxic effect of the cation together with the osmotic pressure. In addition, Membre and Burlot, ${ }^{33}$ in their study investigating the effects of $\mathrm{pH}, \mathrm{NaCl}$, and temperature on the growth and pectinase production of Pseudomonas marginalis, stated that enzyme production was highly inhibited with the addition of salt.

Phosphate is known to increase enzyme secretion by microorganisms. However, it has been stated in the literature that intensive mixing and aeration in the presence of phosphate increases gel formation excessively, and it is impossible to use high phosphate concentrations during production. ${ }^{34}$ Different concentrations of $\mathrm{K}_{2} \mathrm{HPO}_{4}$ and $\mathrm{KH}_{2} \mathrm{PO}_{4}$ were added to the fermentation medium to determine the effect of phosphate concentration on endopectinase production $\left(0.1 \%(\mathrm{w} / \mathrm{v}) \mathrm{K}_{2} \mathrm{HPO}_{4}+0.1 \%\right.$ $(\mathrm{w} / \mathrm{v}) \mathrm{KH}_{2} \mathrm{PO}_{4} ; 0.3 \%(\mathrm{w} / \mathrm{v}) \mathrm{K}_{2} \mathrm{HPO}_{4}+0.15 \%(\mathrm{w} / \mathrm{v})$ $\mathrm{KH}_{2} \mathrm{PO}_{4} ; 0.6 \%(\mathrm{w} / \mathrm{v}) \mathrm{K}_{2} \mathrm{HPO}_{4}+0.2 \%(\mathrm{w} / \mathrm{v})$ $\left.\mathrm{KH}_{2}^{2} \mathrm{PO}_{4}\right)$. The effects of different phosphate concentrations on endo-pectinase activity is given in Fig. 7. The highest endo-pectinase activity was obtained at $0.3 \% \mathrm{~K}_{2} \mathrm{HPO}_{4}+0.15 \%(\mathrm{w} / \mathrm{v}) \mathrm{KH}_{2} \mathrm{PO}_{4}$ concentration. The maximum endo-pectinase activity obtained was $20.51 \mathrm{U} \mathrm{mL}^{-1}$ at $84 \mathrm{~h}$. It is stated in literature that inorganic phosphate increased the for- 


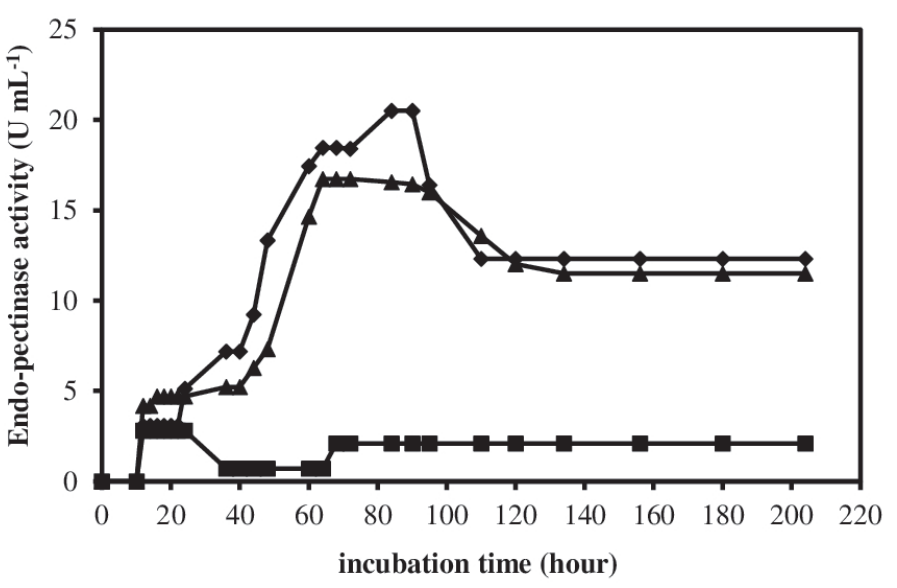

Fig. 7 - Effect of different $\mathrm{K}_{2} \mathrm{HPO}_{4}-\mathrm{KH}_{2} \mathrm{PO}_{4}$ concentrations on endo-pectinase production by Bacillus pumilus NRRL B-212 $\left(\mathrm{pH}=8, \mathrm{~T}: 30^{\circ} \mathrm{C}\right.$, agitation rate: $150 \mathrm{rpm}$, Cpectin: $1 \%(\mathrm{w} / \mathrm{v})$, $\mathrm{K}_{2} \mathrm{HPO}_{-} \mathrm{KH}_{2} \mathrm{PO}$ concentrations; $\mathbf{\square}: 0.1-0.1 \%,: 0.3-0.15 \%$ $\Delta: 0.6-0.2 \%(w / v))$

mation of the polygalacturonic acid transeliminase of Aeromonas liquefaciens. Pectinase production of Erwinia aroideae increased with inorganic phosphate at concentrations in the range of $0.1-0.5 \mathrm{M}$, and was found to be approximately $0.15 \mathrm{M}$ optimum concentration. ${ }^{35}$

\section{Endo-pectinase production from sugar beet pulp by solid-state fermentation}

At this stage of the study, endo-pectinase was produced from sugar beet pulp by solid-state fermentation. Experiments were carried out by adding yeast extract, $\left(\mathrm{NH}_{4}\right)_{2} \mathrm{SO}_{4}$, and peptone as nitrogen sources to the medium in which sugar beet pulp (5 $\%, \mathrm{w} / \mathrm{v}$ ) was used as a solid substrate. Low enzyme activity was determined in the fermentation medium without nitrogen source. Endo-pectinase activity was determined as $34.41 \mathrm{U} \mathrm{mL}^{-1}$ on day 5 . When peptone $(0.3 \%, \mathrm{w} / \mathrm{v})$ was used as a nitrogen source, it was determined that it slightly increased the production of endo-pectinase. Endo-pectinase activity was obtained as $34.92 \mathrm{U} \mathrm{mL}^{-1}$ on day 5 in the fermentation medium containing sugar beet pulp ( $5 \%$, $\mathrm{w} / \mathrm{v})+$ peptone. Therefore, it was concluded that peptone is insufficient for the synthesis of pectinase group enzymes. It was also determined that the production of endo-pectinase increased considerably in fermentation media supplemented with ammonium sulphate $(0.3 \%, \mathrm{w} / \mathrm{v})$ and yeast extract $(0.3 \%$, $\mathrm{w} / \mathrm{v})$. Endo-pectinase activities obtained on day 5 in media containing sugar beet pulp $(5 \%, \mathrm{w} / \mathrm{v})+$ $\left(\mathrm{NH}_{4}\right)_{2} \mathrm{SO}_{4}$, and sugar beet pulp $(5 \%, \mathrm{w} / \mathrm{v})+$ yeast extract were 79.28 and $39.64 \mathrm{U} \mathrm{mL}^{-1}$, respectively. In the light of these data, it can be stated that $\left(\mathrm{NH}_{4}\right)_{2} \mathrm{SO}_{4}$ and yeast extract in the medium containing sugar beet pulp are beneficial for endo-pectinase production by Bacillus pumilus NRRL B-212.

\section{Optimization of endo-pectinase production by RSM}

In RSM experiments, sugar beet pulp was used as agricultural waste and supplemented with ammonium sulphate and yeast extract. Many statistical experimental designs such as the response surface methodology have been used in the optimization of enzyme production with microorganisms. ${ }^{36,7}$ RSM was used to investigate the effects of the substrate concentrations on endo-pectinase production and their dosages were optimized. The concentrations of the substrates were selected as the independent variables. Twenty experiments were conducted. According to preliminary test results, sugar beet pulp amount was selected between $2 \%$ and $8 \%$, while yeast extract and $\left(\mathrm{NH}_{4}\right)_{2} \mathrm{SO}_{4}$ were selected between 0 and $0.6 \%$. The results obtained are given in Tables 2 and 3 .

According to the ANOVA values, the fit of the data to the model is very important. For instance, Fisher's F-test, which is the measure of the distance of the data from the distribution, was $\mathrm{F}_{\text {model }}=7.16$, with low probability value $\left(\left(\mathrm{p}_{\text {model }}>\mathrm{F}\right) \stackrel{\mathrm{model}}{=} 0.0025\right)$. Probability value less than 0.05 indicates that the model terms are meaningful. In addition, determination coefficient of 0.87 is an indicator of the suitability of the model; in other words, $13 \%$ of the total variation could not be explained with the model. This is especially within a highly acceptable range in biological production processes.

Adjusted (Adj) $R^{2}$ value was found to be 0.74 in the created model. This value is in agreement with the $R^{2}$ value. Adequate precision value of 8.604 indicated a suitable signal and supported that the model can be used within the design area. Regression equation in coded unit obtained from RSM analysis gave the empirical relationship between endo-pectinase activity and process variables (sugar beet pulp (A), $\left(\mathrm{NH}_{4}\right)_{2} \mathrm{SO}_{4}(\mathrm{~B})$, and yeast extract (C) concentrations);

Endo-pectinase activity $=+99.36+\mathbf{3 2 . 8 5} \mathbf{A}$

$+1.26 \mathrm{~B}+10.34 \mathrm{C}+\mathbf{1 5 . 5 2} \mathbf{A B}-1.60 \mathrm{AC}$

$-8.81 \mathrm{BC}-3.58 \mathrm{~A}^{2}-\mathbf{1 6 . 3 2} \mathrm{B}^{2}+0.88 \mathrm{C}^{2}$

The significance of the model can also be understood by the low probability value (P-value $<0.05)$. Comparing the $\mathrm{P}$ values of the coefficients, $\mathrm{P}$-values of $\mathrm{A}, \mathrm{AB}$, and $\mathrm{B}^{2}$ less than 0.05 indicated that the effects of these process variables were significant, and the changes to be made in these variables will change the enzyme production. "Lack of fit" was found to be important for endo-pectinase activity. Since we did not exclude expressions with a high $P$ value in the quadratic equation in ANOVA for endo-pectinase activities, the lack of fit was significant and fitted a higher-order model. However, 
Table $2-C C D$ matrix, response factor results

\begin{tabular}{|c|c|c|c|c|c|c|}
\hline \multirow{3}{*}{ Runs } & \multicolumn{3}{|c|}{ Variables } & \multirow{2}{*}{\multicolumn{3}{|c|}{$\frac{\text { Response }}{\text { Endo-pectinase activity }\left(\mathrm{U} \mathrm{mL}^{-1}\right)}$}} \\
\hline & \multirow{2}{*}{ A } & \multirow{2}{*}{ B } & \multirow{2}{*}{$\mathrm{C}$} & & & \\
\hline & & & & Exp. & Predic. & Residual \\
\hline 1 & 8.0 & 0.3 & 0.3 & 118.92 & 144.48 & -25.56 \\
\hline 2 & 3.22 & 0.12 & 0.48 & 86.49 & 82.49 & 4.00 \\
\hline 3 & 5.0 & 0.3 & 0.3 & 93.69 & 99.36 & -5.67 \\
\hline 4 & 6.78 & 0.48 & 0.48 & 145.75 & 129.88 & 15.87 \\
\hline 5 & 5.0 & 0.3 & 0.3 & 100.90 & 99.36 & 1.54 \\
\hline 6 & 3.22 & 0.48 & 0.48 & 54.05 & 36.35 & 17.70 \\
\hline 7 & 6.78 & 0.12 & 0.12 & 82.88 & 78.86 & 4.02 \\
\hline 8 & 5.0 & 0.3 & 0.3 & 100.90 & 99.36 & 1.54 \\
\hline 9 & 5.0 & 0.0 & 0.3 & 39.64 & 51.08 & -11.44 \\
\hline 10 & 5.0 & 0.3 & 0.3 & 109.99 & 99.36 & 10.63 \\
\hline 11 & 3.22 & 0.12 & 0.12 & 46.85 & 41.00 & 5.85 \\
\hline 12 & 5.0 & 0.3 & 0.3 & 93.24 & 99.36 & -6.12 \\
\hline 13 & 3.22 & 0.48 & 0.12 & 28.83 & 30.10 & -1.27 \\
\hline 14 & 5.0 & 0.3 & 0.3 & 102.70 & 99.36 & 3.34 \\
\hline 15 & 5.0 & 0.3 & 0.6 & 93.69 & 119.22 & -25.53 \\
\hline 16 & 6.78 & 0.48 & 0.12 & 147.75 & 130.03 & 17.72 \\
\hline 17 & 5.0 & 0.3 & 0.0 & 79.28 & 84.46 & -5.18 \\
\hline 18 & 6.78 & 0.12 & 0.48 & 136.94 & 113.95 & 22.99 \\
\hline 19 & 2.0 & 0.3 & 0.3 & 28.83 & 33.99 & -5.16 \\
\hline 20 & 5.0 & 0.6 & 0.3 & 36.04 & 55.31 & -19.27 \\
\hline
\end{tabular}

Table 3 -Analysis of variance (ANOVA) for a quadratic polynomial (quadratic) model of endo-pectinase activity as a function of medium components

\begin{tabular}{|c|c|c|c|c|c|}
\hline Source & Sum of squares & DF & Mean square & F- value & Probability $(\mathrm{p})>\mathrm{F}$ \\
\hline Model & $22,784.46$ & 9 & $2,531.61$ & 7.16 & 0.0025 significant \\
\hline A-Sugar beet pulp & $14,736.44$ & 1 & $1,4736.44$ & 41.69 & $<0.0001$ \\
\hline B-Ammonium sulphate & 21.58 & 1 & 21.58 & 0.061 & 0.8099 \\
\hline C- Yeast extract & $1,458.95$ & 1 & $1,458.95$ & 4.13 & 0.0696 \\
\hline $\mathrm{AB}$ & $1,926.34$ & 1 & $1,926.34$ & 5.45 & 0.0417 \\
\hline $\mathrm{AC}$ & 20.48 & 1 & 20.48 & 0.058 & 0.4034 \\
\hline $\mathrm{BC}$ & 620.93 & 1 & 620.93 & 1.76 & 0.2145 \\
\hline $\mathrm{A}^{2}$ & 184.77 & 1 & 184.77 & 0.52 & 0.4862 \\
\hline $\mathrm{B}^{2}$ & $3,838.81$ & 1 & $3,838.81$ & 10.86 & 0.0081 \\
\hline $\mathrm{C}^{2}$ & 11.10 & 1 & 11.10 & 0.031 & 0.8629 \\
\hline Residual & $3,534.41$ & 10 & 353.4 & & \\
\hline Lack of fit & $3,340.52$ & 5 & 668.10 & 17.23 & 0.0036 significant \\
\hline Pure error & 193.89 & 5 & 38.78 & & \\
\hline Corrected total & $26,318.87$ & 19 & & & \\
\hline
\end{tabular}

$R^{2} ; 0.87$, Adj $R^{2} ; 0.74$, Pred $R^{2} ; 0.02$, Adeq Precision; 8.604 
Endo-pectinase activity

Color points by value of Endo-pectinase activity: 147.75 28.83

Endo-pectinase activity

- Endo-pectinase activity

Actual Factors

A: Sugar beet pulp $=5.00$

B: Ammonium sulphate $=0.30$

C: Yeast extract $=0.30$
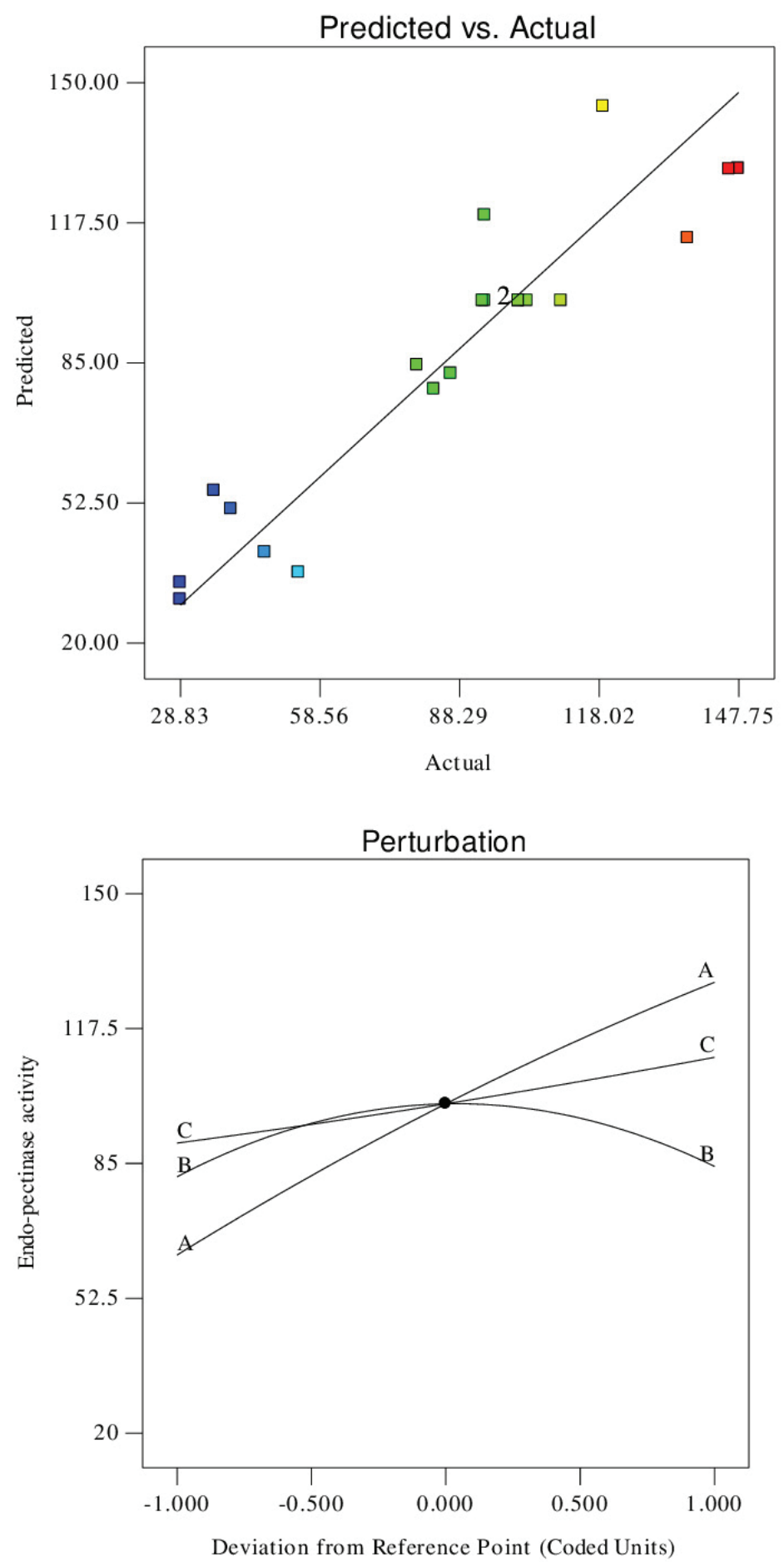

Fig. 8 - a) The actual data versus predicted data b) perturbation plot showing the effect of each of the independent variables on endo-pectinase activity

the principle of the program cuts the Taylor series in quadratic order and has no affect on the model in our range. Relationship between observed values versus estimated values using the model equation is given in Fig. 8(a). As may be seen from the figure, the relationship between the experimental actual values and the values estimated from the model was at an acceptable limit for biological systems. Fig. 8(b) shows the changes of endo-pectinase activity with $\mathrm{A}, \mathrm{B}$, and $\mathrm{C}$ according to the reference point.

Three-dimensional and contour curves showing the change in endo-pectinase activity according to concentrations of sugar beet pulp, $\left(\mathrm{NH}_{4}\right)_{2} \mathrm{SO}_{4}$, and yeast extract are shown in Fig. 9. As seen in the contour (projection) graphs, the curves of the obtained response values are shown on a plane. The 


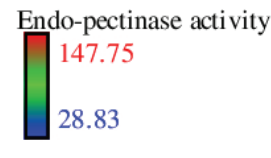

$\mathrm{X} 1$ = A: Sugar beet pulp $\mathrm{X} 2=\mathrm{B}$ : Ammonium sulphate

Actual Factor

C: Yeast extract $=0.30$

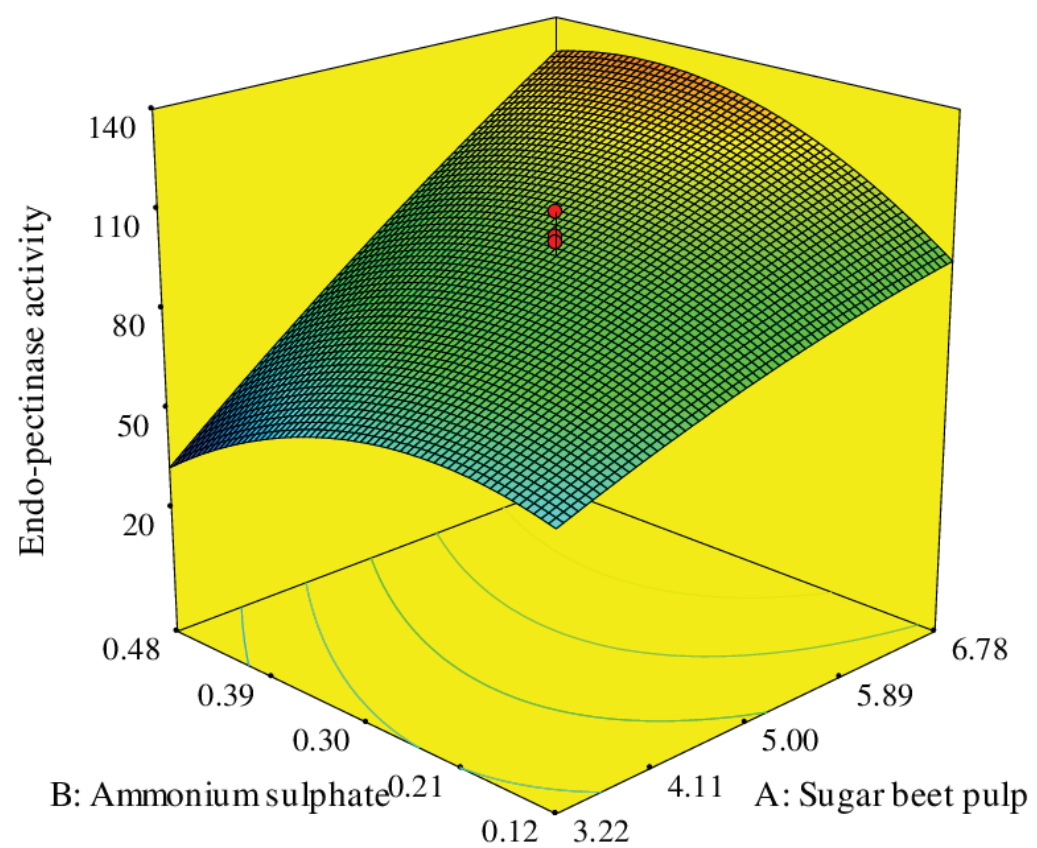

Endo-pectinase activity

Design Points

147.75

28.83

$\mathrm{X} 1$ = A: Sugar beet pulp $\mathrm{X} 2$ = B: Ammonium sulphate

Actual Factor

C: Yeast extract $=0.30$

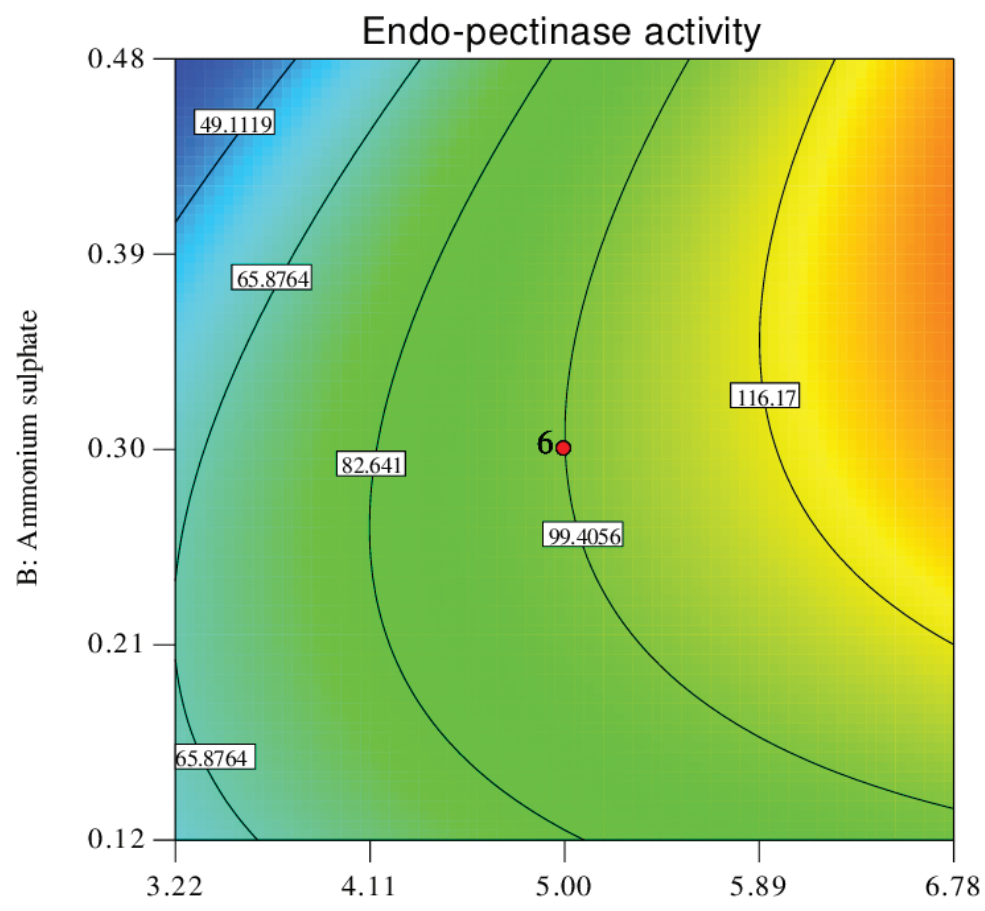

A: Sugar beet pulp

Fig. 9 -Response surface plots for endo-pectinase activity 


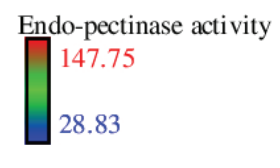

$\mathrm{X} 1=\mathrm{A}:$ Sugar beet pulp $\mathrm{X} 2=\mathrm{C}$ : Yeast extract

Actual Factor

B: Ammonium sulphate $=0.30$

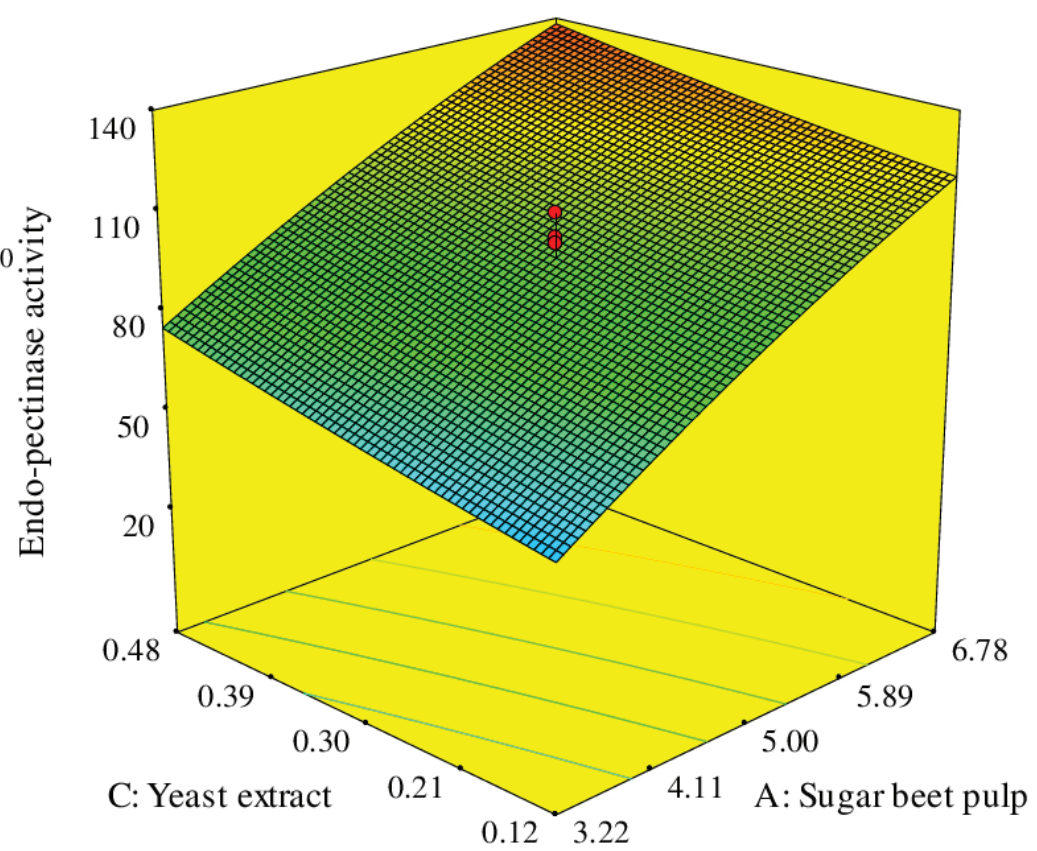

Endo-pectinase activity

글 Design Points

147.75

28.83

$\mathrm{X} 1$ = A: Sugar beet pulp $\mathrm{X} 2=\mathrm{C}$ : Yeast extract

Actual Factor

B: Ammonium sulphate $=0.30$

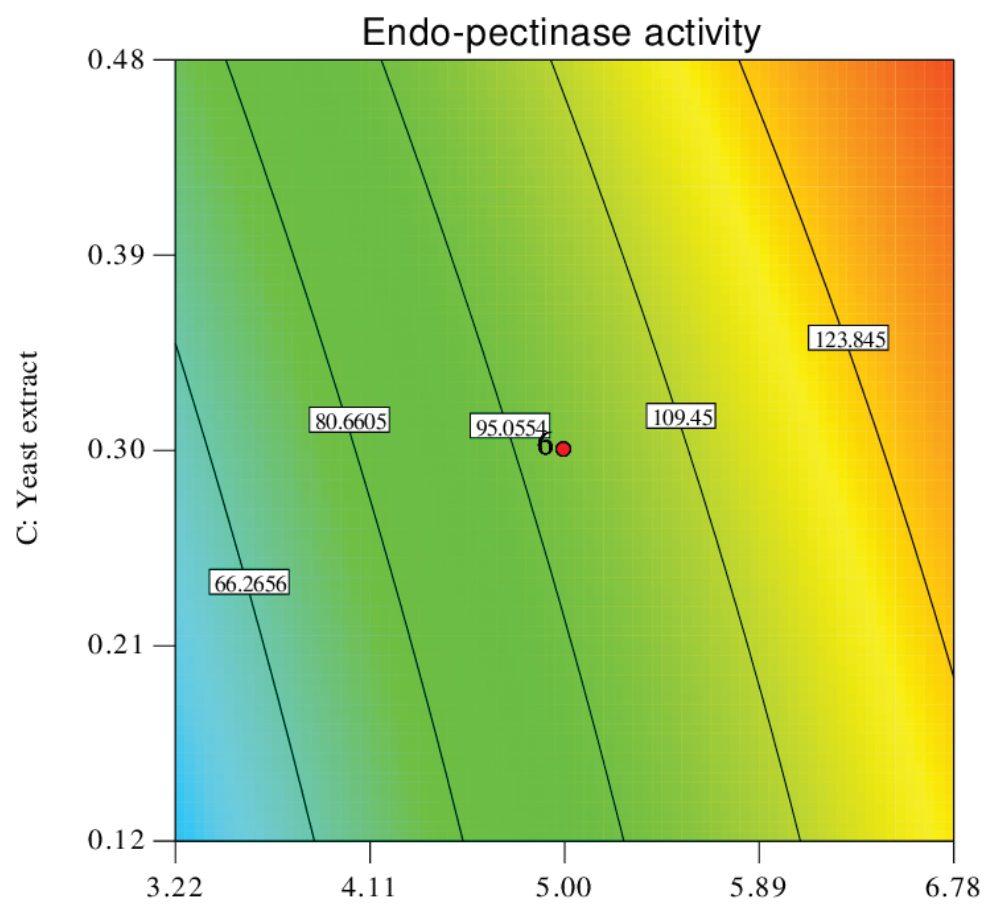

A: Sugar beet pulp

Fig. 9 - continued 


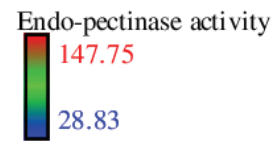

$\mathrm{X} 1=\mathrm{B}:$ Ammonium sulphate $\mathrm{X} 2=\mathrm{C}$ : Yeast extract

Actual Factor

A: Sugar beet pulp $=5.00$
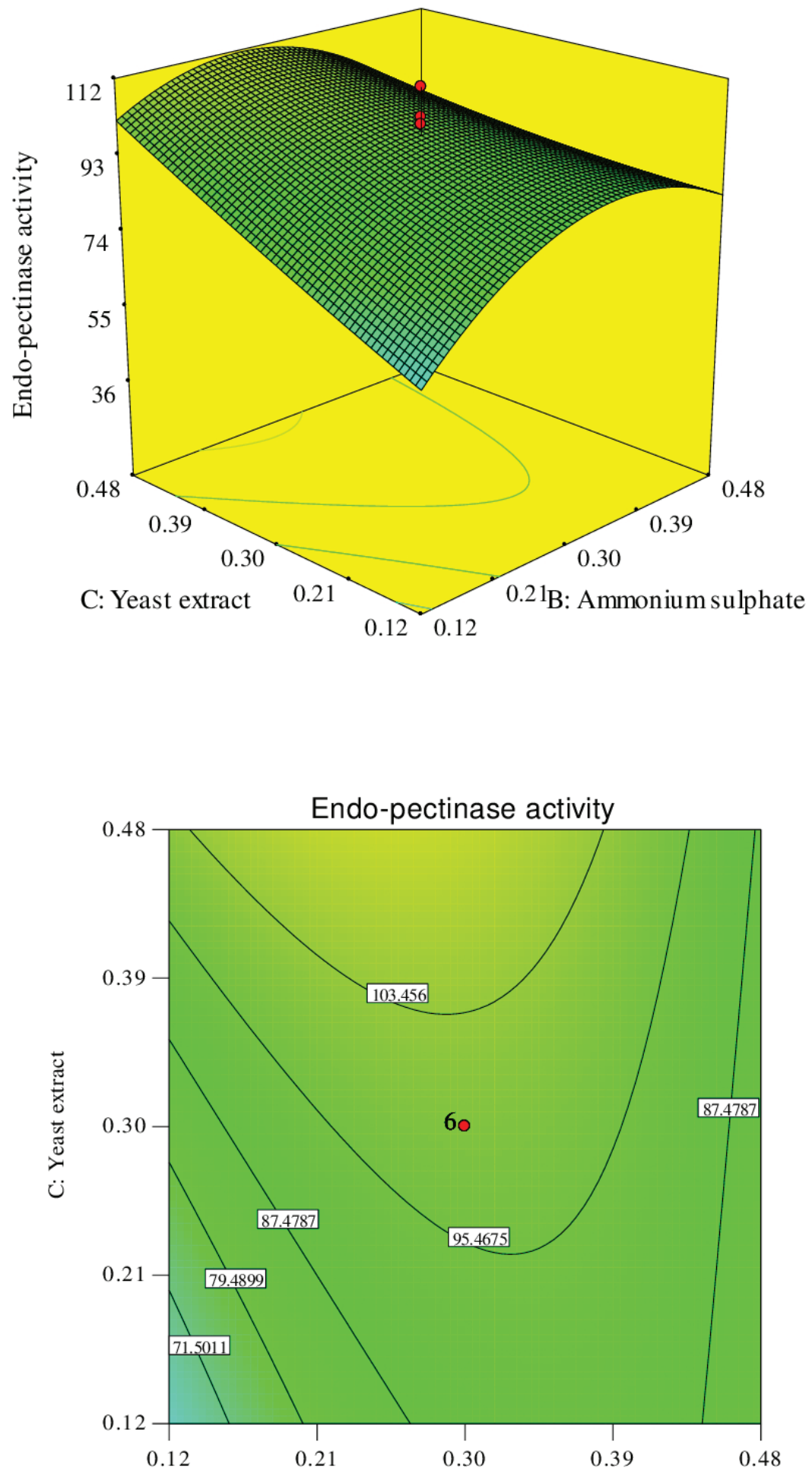

B: Ammonium sulphate

Fig. 9 -continued 
coordinates of this plane show the levels of the independent variables. From the figures, it may be seen that, as sugar beet pulp and yeast extract concentrations increased, enzyme production increased, and the ammonium sulphate concentration range in which the endo-pectinase activity should be the highest was approximately $0.21-0.48 \%(\mathrm{w} / \mathrm{v})$. The highest endo-pectinase activity was obtained as $147.75 \mathrm{U} \mathrm{mL}^{-1}$ in medium containing $6.78 \%$ sugar beet pulp, $0.48 \%\left(\mathrm{NH}_{4}\right)_{2} \mathrm{SO}_{4}$, and $0.12 \%$ yeast extract. This value was considerably higher than the activities obtained in submerged fermentation.

\section{Conclusions}

In this study, endo-pectinase production by $B$. pumilus was performed by both submerged and solid-state fermentation. Effects of initial $\mathrm{pH}$, carbon and nitrogen sources, salts and phosphate were investigated on submerged fermentation. The maximum endo-pectinase production was achieved in the medium with $\mathrm{pH} 8,1 \%(\mathrm{w} / \mathrm{v})$ pectin, $0.05 \%$ (w/v) ammonium sulphate, and $0.3 \% \mathrm{~K}_{2} \mathrm{HPO}_{4}+$ $0.15 \%(\mathrm{w} / \mathrm{v}) \mathrm{KH}_{2} \mathrm{PO}_{4}$. Furthermore, sugar beet pulp, which is an agricultural waste, was transformed into a value-added product, namely, endo-pectinase through fermentation. The production of endo-pectinase from sugar beet pulp by Bacillus pumilus NRRL B-212 was optimized by RSM. This methodology has been successfully applied to clutch effects and the interaction between components. A, $\mathrm{AB}$, and $\mathrm{B}^{2}$ are important model terms for endo-pectinase activity. With the high activity values obtained, it was determined that this enzyme has great potential especially in industrial applications.

\section{ACKNOWLEDGMENTS}

This paper includes a part of Ph.D thesis data of Ozlem TEPE.

\section{FUNDING}

This work was financially supported by the Firat University Scientific Research Projects Management Unit (FUBAP), Turkey (Grant no. FUBAP 1674).

\section{CONFLICTS OF INTEREST}

No conflict of interest was declared by the authors.

\section{References}

1. Amin, F., Mohsin, A., Nawaz Bhatti, H., Bilal, M., Production, thermodynamic characterization, and fruit juice quality improvement characteristics of an exo-polygalacturonase from Penicillium janczewskii, BBA-Proteins Proteom. 1868 (2020) 140379.

doi: https://doi.org/10.1016/j.bbapap.2020.140379
2. Karaoğlan, M., Erden-Karaoğlan, F., Effect of codon optimization and promoter choice on recombinant endopolygalacturonase production in Pichia pastoris, Enzyme Microb. Tech. 139 (2020) 109589.

doi: https://doi.org/10.1016/j.enzmictec.2020.109589

3. Govindaraji, P. K., Vирpu, S., Characterisation of pectin and optimization of pectinase enzyme from novel Streptomyces fumigatiscleroticus VIT-SP4 for drug delivery and concrete crack-healing applications: An eco-friendly approach, Saudi J. Biol. Sci. 27 (2020) 3529. doi: https://doi.org/10.1016/j.sjbs.2020.07.024

4. Sharma, D., Sharma, G., Mahajan, R., Development of strategy for simultaneous enhanced production of alkaline xylanase-pectinase enzymes by a bacterial isolate in short submerged fermentation cycle, Enzyme Microb. Tech. 122 (2019) 90 .

doi: https://doi.org/10.1016/j.enzmictec.2018.12.008

5. Mihajlovski, K. R., Radovanovic, N. R., Veljovic, Đ. N., Siler-Marinkovic, S. S., Dimitrijevic-Brankovic, S. I., Improved $\alpha$-amylase production on molasses and sugar beet pulp by anovel strain Paenibacillus chitinolyticus CKS1, Ind. Crop. Prod. 80 (2016) 115. doi: https://doi.org/10.1016/j.indcrop.2015.11.025

6. Nigam, P., Process selection for protein-enrichment: Fermentation of the sugar industry by-products molasses and sugar beet pulp, Process Biochem. 29 (1994) 342. doi: https://doi.org/10.1016/0032-9592(94)87002-0

7. Grohmann, K., Bothast, R. J., Pectin-rich residues generated by processing of citrus-fruits, apples, and sugar-beets - enzymatic-hydrolysis and biological conversion to value-added products, ACS Symposium Series, Symposium on Enzymatic Conversion of Biomass for Fuels Production, 205th National Meeting of the American-Chemical-Society, 566 (1994) 390.

8. Muir, B. M., Anderson, A. R., Development and diversification of sugar beet in Europe, Sugar Tech. doi: https://doi.org/10.1007/s12355-021-01036-9

9. Li, Z., Bai, Z., Zhang, B., Xie, H., Hu, Q., Hao, C., Xue, W., Zhang, $H$., Newly isolated Bacillus gibsonii S-2 capable of using sugar beet pulp for alkaline pectinase production, World J. Microb. Biot. 21 (2005) 1486. doi: https://doi.org/10.1007/s11274-005-7025-8

10. Taskin, E., Eltem, R., The enhancement of polygalacturonase and polymethylgalacturonase production on solid-state conditions by Aspergillus foetidus, Food Biotechnol. 22 (2008) 217. doi: https://doi.org/10.1080/08905430802262533

11. Tepe, O., Dursun, A. Y., Exo-pectinase production by Bacillus pumilus using different agricultural wastes and optimizing of medium components using response surface methodology, Environ. Sci. Pollut. Res. 21 (2014) 9920. doi: https://doi.org/10.1007/s11356-014-2833-8

12. Cheilas, T., Stoupis, T., Christakopoulos, P., Katapodis, P., Mamma, D., Hatzinikolaou, D. G., Kekos, D., Macris, B. J., Hemicellulolytic activity of Fusarium oxysporum grown on sugar beet pulp. Production of extracellular arabinanase, Process Biochem. 35 (2000) 561. doi: https://doi.org/10.1016/S0032-9592(99)00103-X

13. Tepe, O., Dursun, A. Y., Optimization of endo-pectinase and pectin lyase production from wheat bran by Bacillus pumilus using response surface methodology, Gazi U. J. Sci. 34(2) (2021) 335. doi: https://doi.org/10.35378/gujs.808326

14. Tepe, O., Dursun, A. Y., Bioprocess parameters and oxygen transfer characteristics in pectin lyase production by Bacillus pumilus, Fresen. Environ. Bull. 26(8) (2017) 5082. 
15. Mill, P. J., Tuttobello, R., The pectic enzymes of Aspergillus niger 2. Endopolygalacoturonase, Biochem. J. 79 (1961) 64.

doi: https://doi.org/10.1042/bj0790057

16. Tuttobello, R., Mill, P. J., The pectic enzymes of Aspergillus niger 1 . The production of active mixtures of pectic enzymes, Biochem. J. 79 (1961) 57. doi: https://doi.org/10.1042/bj0790051

17. Elibol, M., Optimization of medium composition for actinorhodin production by Streptomyces coelicolor A3(2) with response surface methodology, Process Biochem. 39 (2004) 1062. doi: https://doi.org/10.1016/S0032-9592(03)00232-2

18. Murad, H. A., Azzaz, H. H., Microbial pectinases and ruminant nutrition, Res. J. Microbiol. 6(3) (2011) 246. doi: https://doi.org/10.3923/jm.2011.246.269

19. Ahlawat, S., Dhiman, S. S., Battan, B., Mandhan, R. P., Sharma, J., Pectinase production by Bacillus subtilis and its potential application in biopreparation of cotton and micropoly fabric, Process Biochem. 44 (2009) 521. doi: https://doi.org/10.1016/j.procbio.2009.01.003

20. Galiotou-Panayotou, M., Kapantai, M., Kalantzi, O., Growth conditions of Aspergillus sp. ATHUM-3482 for polygalacturonase production, Appl. Microbiol. Biotechnol. 47 (1997) 425. doi: https://doi.org/10.1007/s002530050951

21. Dhillon, S. S., Gill, R. K., Gill, S. S., Singh, M., Studies on the utilization of citrus peel for pectinase production using fungus Aspergillus niger, Int. J. Environ. Stud. 61(2) (2004) 199. doi: https://doi.org/10.1080/0020723032000143346

22. Stutzenberger, F. J., Inducible thermoalkalophilic polygalacturonate lyase from Thermomonospora fusca, J. Bacteriol. 169(6) (1987) 2774. doi: https://doi.org/10.1128/jb.169.6.2774-2780.1987

23. Silva, D., Tokuioshi, K., Martins, S. E., Silva, R., Gomes, $E$., Production of pectinase by solid-state fermentation with Penicillium viridicatum RFC3, Process Biochem. 40 (2005) 2885. doi: https://doi.org/10.1016/j.procbio.2005.01.008

24. Abbasi, H., Fazaelipoor, H. M., Pectinase production in a defined medium using surface culture fermentation, Int. J. Ind. Chem. 1(1) (2010) 5.

25. Özeş, O. N., Determination of physiological parameters affecting the polygalacturonase synthesis of Aspergillus niger and investigation of some kinetic properties of the enzyme, Science Thesis, Hacettepe University (1988), Ankara, Turkey.

26. Galiotou-Panayotou, M., Rodis, P., Kapantai, M., Enhanced polygalacturonase production by Aspergillus niger NRRL364 grown on supplemented citrus pectin, Lett. Appl. Microbiol. 17 (1993) 145. doi: https://doi.org/10.1111/j.1472-765X.1993.tb00380.x

27. Ouattara, H. G., Reverchon, S., Niamke, S. L., Nasser, W., Molecular identification and pectate lyase production by
Bacillus strains involved in cocoa fermentation, Food Microbiol. 28 (2011) 1. doi: https://doi.org/10.1016/j.fm.2010.07.020

28. Nabi, N. G., Asgher, M., Shah, A. H., Sheikh, M. A., Asad, M. J., Production of pectinase by Trichoderma harzianum in solid state fermentation of citrus peel, Pak. J. Agri. Sci. 40(3-4) (2003) 193

29. Tanyıldızı, M. S., Investigation of a-amylase production in different environments and working conditions with various bacterial species, Firat University, Institute of Science, PhD Thesis, (2005) Elazığ, Turkey.

30. Shevchik, V. E., Robert-Baudouy, J., Hugouvieux-Cotte-Pattat, N., Pectate lyase PelI of Erwinia chrysanthemi 3937 belongs to a new family, J. Bacteriol. 179 (1997) 7321. doi: https://doi.org/10.1128/jb.179.23.7321-7330.1997.

31. Kobayashi, T., Koike, K., Yoshimatsu, T., Higaki, N., Suzumatsu, A., Ozawa, T., Hatada, Y., Ito, S., Purification and properties of a low-molecular-weight, high-alkaline pectate lyase from an alkaliphilic strain of Bacillus, Biosci. Biotechnol. Biochem. 63(1) (1999) 65. doi: https://doi.org/10.1271/bbb.63.65

32. Gummadi, S. N., Kumar, S., Aneesh, C. N. A., Effect of salts on growth and pectinase production by halotolerant yeast, Debaryomyces nepalensis NCYC 3413, Curr. Microbiol. 54 (2007) 472. doi: https://doi.org/10.1007/s00284-007-0060-y

33. Membre, J. M., Burlot, P. M., Effects of temperature, $\mathrm{pH}$, and $\mathrm{NaCl}$ on growth and pectinolytic activity of Pseudomonas marginalis, Appl. Environ. Microbiol. 60(6) (1994) 2017. doi: https://doi.org/10.1128/aem.60.6.2017-2022.1994

34. Antov, M., Pericin, D., Effect of some inorganic salts on the partitioning of pectinase of Polyporus squamosus in polyethylene glycol/crude dextran aqueous two-phase system, World J. Microb. Biot. 19 (2003) 151. doi: https://doi.org/10.1023/A:1023283316186

35. Tomizawa, H., Izaki, K., Takahashı, H., Stimulation of pectolytic enzyme formation of Erwinia aroideae by an active factor in carrot extracts Part II. Partial purification of the factor and the stimulating effect of some other compounds, Agr. Biol. Chem. 34(7) (1970) 1064. doi: https://doi.org/10.1080/00021369.1970.10859735

36. Dutta, J. R., Dutta, P. K., Banerjee, R., Optimization of culture parameters for extracellular protease production from a newly isolated Pseudomonas sp. using response surface and artificial neural network models, Process Biochem. 39 (2004) 2193. doi: https://doi.org/10.1016/j.procbio.2003.11.009

37. Barbosa, A. M., Giese, E. C., Dekker, R. F. H., Borsato, D., Briones Perez, A. I., Ubede Iranzo, J. U., Extracellular $\beta$-glucosidase production by the yeast Debaryomces pseudopolymorphus UCLM-NS/A: Optimization using surface methodology, New Biotech. 27(4) (2010) 374. doi: https://doi.org/10.1016/j.nbt.2010.05.013 